\title{
Doç. Dr. ŞiŞMAN, Bekir; Türk Kültüründe Evlilik (Geleneğin Son Yüzyılı - Samsun Örneği), Kurgan Edebiyat Yayınları: 182, Edebiyat Dil Araştırma ve İnceleme Dizisi: 73, Ankara 2017, XV+264 s. ISBN: 978-605-2030-24-0
}

\section{Mustafa EREN*}

1969 yılı Samsun doğumlu olan Bekir ŞİŞMAN, önsözde de belirttiği gibi bu âlemde maksûd olan birkaç şeyden biri olan oğul evlendirmek geleneğini Samsun özelinde ele alarak Türk Kültüründe Evlilik üzerine yazdığı kitapla bu alandaki önemli bir boşluğu doldurmuştur. Kitabın halk bilimi alanının duayenlerinden biri olan Prof. Dr. Mehmet Öcal OĞUZ'a ithaf edilmesi de bu çalışmanın ne kadar önemli olduğunu bizlere göstermektedir.

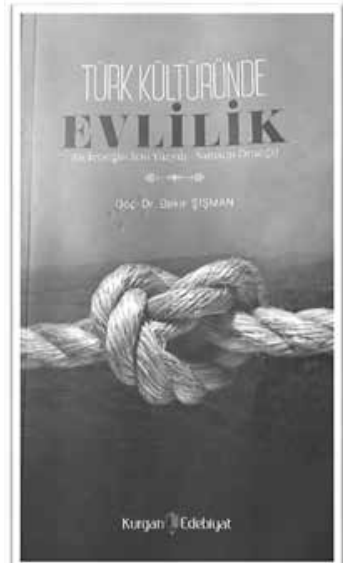

Evlilik kurumunun ve dügün âdetlerinin akademik anlamda incelenmesi Türk kültür tarihi açısından çok önemlidir. Bu düşünce ile ele alınan çalışmada asıl amaç Cumhuriyet Dönemindeki kültür değişimini Eski Türklerden günümüze Türk evlenme âdetleri örneğinde tespit ve tetkik edebilmektir.

Evlilik töresi ve bu töreye ait geleneklerin Türk kültür evrenindeki karşıllı̆̆, Göktürk Abideleri ve Divân-1 Lugat'it-Türk başta olmak üzere yazılı kaynaklardan yararlanılarak ortaya konulmaya

* Giresun Üniversitesi, Sosyal Bilimler Enstitüsü, Türk Dili ve Edebiyatı Anabilim Dalı, Doktora Öğrencisi. Türkiye. Elmek: kutaymustafa@hotmail.com 
çalışılmıştır. Çalışmada özellikle Oğuz Türklerinin göç coğrafyası izlenmiş; Eski Türklerden başlayarak Selçuklulara, oradan da Osmanlılara ve nihayet Türkiye Cumhuriyetine uzanan tarihi süreçte yaşatılan Türk evlenme âdetleri hakkında örnekler sunulmuştur. Ayrıca Türk evlilik âdetlerinin edebî ve tarihî eserlerde yer alış biçimlerine de yazılı kaynaklardan yararlanılarak yer verilmiştir. Cumhuriyet Dönemi için ise Samsun İli üzerinde durulmuştur.

Türkiye'de geçmişte ve günümüzde var olan evlilik türlerinin, evlilik sınıflandırmasının ve evlenme yaşının ayrıntılı olarak ele alındığı giriş bölümünden başka kitapta altı bölüm bulunmaktadır. Altı bölümün ardından sonuç, belgeler, kaynak kişiler, kaynaklar ve fotoğraflar bölümleri gelmektedir.

Giriş bölümünde evliliğin genel tanımları yapılmış, Eski Türk inanç sisteminde evlilik kültürünün "ocak, ocak kurma" ile özdeşleştiği dile getirilmiştir. Ayrıca bu bölümde Türkiye'de geçmişte ve günümüzde var olan evlilik türleri: Beşik kertmesi, söz alma-söz verme, berder evlilik, taygeldi evlilik gibi sınıflandırmalar yapılarak anlatılmıştır. Türkiye'deki evliliklerin çevreye, eş sayısına ve yapılan tercihe göre istatistiklerinin, evlenme yaşının yıllara göre yaş ortalamalarının verilmesiyle giriş bölümü sona ermektedir.

Türk kültür evreni bağlamında evlenme âdetleri; kavramlar, gelenekler ve törenler adını taşıyan birinci bölümde evlilik kültürüyle ilgili Divânü Lügat'itTürk, Dede Korkut Oğuznâmeleri ve Surnâmelerden alıntılar yapılmış; özellikle de 1897 yılında Alman Şarkiyatçı D. Theophil Löbel'in yayımladığ 1 "Türkiye'de Evlilik Âdetleri” adlı kitabı referans gösterilmiştir. Bu bölümde eş seçme, Eski Türklerde "kalın" diye ifade edilen günümüzdeki başlık âdetleri, görücü çıkarma, kız isteme, nişan, çeyiz, ev açma geleneği, düğüne davet, kına, düğün ve gelin alma (göçürme, indirme) geleneği, saçı saçma, nikâh, güvey, sağdıç, yengelik, gerdek, yüz görümlüğü, duvak, hediye ve bağış, geriliğe gitme gelenekleri ve dügünlerin işlevselliği üzerinde durulmuştur. Bu geleneklerin Anadolu'nun farklı bölgelerindeki varyantlarından örnekler verilerek, Eski Türklerdeki uygulamaları da kaynaklardan yararlanılarak anlatılmıştır.

Türklerde evlilik âdetlerinin tarihsel arka planı adını taşıyan ikinci bölümde Eski Türklerde, Orta Asya'da, Selçuklularda, Osmanlılarda ve Meşrutiyet Döneminde evlilik âdetleri üzerinde durulmuş, Eski Türklerde 
dünürler arası çöpçatanlık görevini "aracı", Selçuklularda ise "savcı (arkuçı)" denilen kişilerin yaptığı belirtilmiştir. Selçuklularda başlık, südlük, ağılık, yandıç ve saçı gelenekleri etraflıca anlatılmıştır. Osmanlılarda evlilik âdetleri konusunda Yıldırım Beyazid'in düğünü ve sûrnâmelerden faydalanılmış geniş ve ayrıntılı örnekler verilmiştir. Meşrutiyet Dönemi evlilik âdetleri görücülük (kız isteme), nişan, düğün, düğünün misafirleri, ve son kısım (gerdek gecesi) olarak sinıflandırılmıştır.

Meşrutiyet Dönemi gerdek gecesi âdetleri D. Theophil Löbel'in “Türkiye'de Evlilik Âdetleri” kitabından alıntılarla adım adım ve içtenlikle yansıtılmış damadın gerdek odasına girişi âdet olarak ilk kez kızın adını soruşu, peçesini kaldırması, yüz görümlüğü vermesi, damadın kızın elini hızlıca tutup öpmesi, aralarındaki sohbetler anlatılmış, Türklerin genellikle dudaktan değil yanaktan ve boyundan öptüğü ifade edilmiş̧ir.

Osmanlılarda Yörük Türkmen düğünü kısmında ise Ali Rıza Yalgın'ın “Cenup'ta Türkmen Oynakları” adlı 1922 y1lına ait derlemelerinden faydalanılmıştır. Bu kısımda Yörüklerde düğün, kına, çeyiz, sağdıç, gerdek gibi düğün âdetleri üzerinde durulmuştur.

Kitabın üęüncü bölümü, tarihî-edebî metinlerde evlilik âdetleri adı altında toplanmıştır. Bu bölümde Köktürk Yazıtlarında, Divânü Lugat'it-Türk'te, Kutadgu Bilig'de, Türk destanlarında, Dede Korkut Hikâyelerinde ve Türk halk hikâyelerinde evlilik âdetleri üzerinde durulmuştur. Köktürk Yazıtlarında geçen evliliğin günümüzde hâlâ mevcut olan "berder" evliliğin benzeri olduğu, Divân-1 Lugat'it-Türk’ten “arkuçı, kalın” gibi sözcüklerin anlamları, Kutadgu Bilig'den evlenilecek kızda bulunması gereken özellikler alıntılar yapılarak anlatılmıştır. Türk destanlarında ve özellikle Manas Destanındaki eş seçme, başlık, dügün, toy gelenekleri üzerinde durulmuştur. Dede Korkut Hikâyelerinden Kam Püre Bey Oğlu Bamsı Beyrek Hikâyesinde anlatılan beşik kertmesi geleneği ve eş adayında bulunması gereken nitelikler ifade edilerek; Kerem ile Aslı, Tahir ile Zühre, Âşık Garip gibi halk hikâyelerinde geçen evlilik gelenekleri anlatılmıştır.

Dördüncü bölümde Samsun'da evlilik âdetlerinin yüzyıl öncesi yer almaktadır. Bu bölümde geçmişte Samsun'da başlık parası ve kız kaçırma nedeniyle yaşanan asayiş olayları ile ilgili yazışmalar, eski nikâhlar, düğün ve 
kına geceleri üzerinde durulmuştur.

Samsun'da evlilik ve düğün âdetlerinin son yarım yüzyılı adını alan beşinci bölümde günümüzde Samsun' da var olan görücüye çıkma, dünürcü gitme, nişan, düğün, duvak töreni, damat sofras1, bürük çekme, gelin basığı ve bohça çıkarma gelenekleri derleme yöntemiyle ele alınıp incelenmiştir. Samsun'un farklı köylerinden örneklerin de dile getirildiği bu bölümde düğün âdetleri hazırlık safhasından, ağırlık götürmeye; gelin hamamından "ciccilik" geleneğine kadar ayrıntılı bir şekilde anlatılmıştır. Ayrıca yine bu kısımda damat bağlanması ve bağlanmanın çözülme yöntemi ile ilgili ritüeller, gerdek gelenekleri, gelin basıklığı ve bundan kurtulma yöntemleri yer almaktadır. Beşinci bölüm Samsun'daki günümüz salon düğünleri, muhafazakâr düğünler ve düğün organizasyon şirketlerinin anlatımıyla sona ermektedir.

Altıncı ve son bölümde evlilik âdetlerinde görülen değişim sosyal ve kültürel olarak ele alınmaktadır. Sosyal değişmenin kaçınılmaz olduğu vurgulanarak "Değişmeyen tek şey değişimin kendisidir." sözü ile konu özetlenmiştir. Sosyal değişimin kültürel değişime neden olduğu ve özellikle kentleşme ve kente göç olgusuyla beraber maddi ve manevi kültürün etkilendiği farklılaşarak değişime uğradığı ifade edilmiştir. Bu değişimlerin evlilik âdet ve geleneklerinde de görüldüğü örneklerle karşılaştırmalar yapılarak anlatılmıştır.

Yazar sonuç bölümünde kültür değişmeleri ve değişimin boyutlarının evlilik âdetleri bağlamında ele alındığını belirterek, geçmişle günümüzün mukayesesinin yapıldığını ve birçok geleneğin artık yok olduğunu veya yok olmaya yüz tuttuğunu ifade etmiştir. Kitabın son bölümünde çalışmaya kaynak olan arşiv belgeleri, kaynak kişiler listesi, kaynaklar ve fotoğraflar da yer almaktadir.

Eserin kapağındaki düğümlü urgan, iki farklı ailenin ve bu aileden iki bireyin yeni hayatlarına geçişinin motifi olarak düğün kavramını çağrıştırmaktadır. Bu düğüm ayrıca damadın bağlanması motifini de akıllara getirmekte esere ayrı bir nitelik kazandırmaktadır. Eski Türklerdeki düğün âdetlerinden, günümüze kadar olan değişimleri Samsun özelinde görebileceğimiz bu kitap, hem bu değişimleri hem de kaybolmaya yüz tutmuş evlilik âdetlerinin gün yüzüne çıkarılıp kayıt altına alınması açısından oldukça önemlidir. Bu tip çalışmaların artması folklorumuzun, 
birlik ve beraberliğimizi sağlayan kültürel değerlerimizin yaşatılması açısından gereklidir.

ilk sözlüktür. XVI. yüzyılda yazılan $A b u s ̧ k a$ lügati iki Türk lehçesi üzerinde yazılan ilk sözlük mahiyetindedir. Çağatayca - Osmanlıca olarak hazırlanan Abuşka lügati Çağatayca eserlerin, özellikle Nevaî eserlerinin Osmanlıcada anlaşılması 